\title{
Haploinsufficiency of ATP6V0C possibly underlies 16p13.3 deletions that cause microcephaly, seizures, and neurodevelopmental disorder
}

Dol:

10.1002/ajmg.a.61905

\section{Document Version \\ Accepted author manuscript}

Link to publication record in Manchester Research Explorer

Citation for published version (APA):

Tinker, R. J., Burghel, G. J., Garg, S., Steggall, M., Cuvertino, S., \& Banka, S. (2020). Haploinsufficiency of ATP6V0C possibly underlies 16p13.3 deletions that cause microcephaly, seizures, and neurodevelopmental disorder. American Journal of Medical Genetics Part A . https://doi.org/10.1002/ajmg.a.61905

Published in:

American Journal of Medical Genetics Part A

\section{Citing this paper}

Please note that where the full-text provided on Manchester Research Explorer is the Author Accepted Manuscript or Proof version this may differ from the final Published version. If citing, it is advised that you check and use the publisher's definitive version.

\section{General rights}

Copyright and moral rights for the publications made accessible in the Research Explorer are retained by the authors and/or other copyright owners and it is a condition of accessing publications that users recognise and abide by the legal requirements associated with these rights.

\section{Takedown policy}

If you believe that this document breaches copyright please refer to the University of Manchester's Takedown Procedures [http://man.ac.uk/04Y6Bo] or contact uml.scholarlycommunications@manchester.ac.uk providing relevant details, so we can investigate your claim.

\section{OPEN ACCESS}


Haploinsufficiency of ATP6VOC possibly underlies 16p13.3 deletions that cause microcephaly, seizures and neurodevelopmental disorder

Rory J Tinker (1), George J Burghel (1), Shruti Garg (2,3), Maggie Steggall (4), Sara Cuvertino $(1,5,6)$, Siddharth Banka $(1,5)$

1. Manchester Centre for Genomic Medicine, St. Mary's Hospital, Manchester University Foundation NHS Trust, Health Innovation Manchester, Manchester, UK.

2. Division of Neuroscience \& Experimental Psychology, School of Biological Sciences, University of Manchester, Manchester, United Kingdom; Manchester Academic Health Science Centre, Manchester University NHS Foundation Trust, Greater Manchester Mental Health NHS Trust, Manchester, United Kingdom.

3. Department of Child and Adolescent Psychiatry, Royal Manchester Children's Hospital, Manchester, UK

4. Department of Paediatric Medicine, Royal Manchester Children's Hospital, Manchester, UK

5. Division of Evolution and Genomic Sciences, School of Biological Sciences, Faculty of Biology, Medicine, and Health, The University of Manchester, Manchester, UK.

6. Division of Cell Matrix Biology and Regenerative Medicine, School of Biological Sciences, Faculty of Biology, Medicine, and Health, The University of Manchester, Manchester, UK

\section{CORRESPONDENCE}

Dr Siddharth Banka

Siddharth.Banka@manchester.ac.uk

Data available on request from the authors

\section{KEY WORDS}

16p13.3 deletion

ATP6V0C

PDPK1

$T B C 1 D 24$

Microcephaly

Seizures

Developmental delay

Autism

\section{DISCLOSURE STATEMENT}

The authors declare no conflict of interest.

\section{AUTHOR CONTRIBUTIONS}

S.B and R.J.T conceived and designed the study. S.B , S.G and M.S were involved in patient care, diagnosis, and treatment. All authors acquired, analyzed, and interpreted the data. R.J.T and S.B drafted he manuscript, which was critically revised by all the authors. 


\section{ABSTRACT}

Introduction: We recently contributed to the description of eight individuals with a novel condition caused by $16 \mathrm{p} 13.3$ microdeletions encompassing TBC1D24, ATP6VOC, and PDPK1 and resulting in epilepsy, microcephaly and neurodevelopmental problems. The phenotypic spectrum, the minimum overlapping region and the underlying disease mechanism for this disorder remain to be clarified.

Results: Here we report a 3.5-year-old male, with microcephaly, autism spectrum disorder and a de novo 16p13.3 microdeletion. We performed detailed in silico analysis to show that the minimum overlapping region for the condition is $\sim 80 \mathrm{~Kb}$ encompassing five protein coding genes. Analysis of loss of function constraint metrics, transcript-aware evaluation of the population variants, GeVIR scores, analysis of reported pathogenic point variants, detailed review of the known functions of gene products and their animal models showed that the haploinsufficiency of ATP6VOC likely underlies the phenotype of this condition. Protein-protein interaction network, gene phenology and analysis of topologically associating domain showed that it was unlikely that the disorder has an epistatic or regulatory basis.

Conclusions: $16 \mathrm{p} 13.3$ deletions encompassing ATP6VOC cause a neurodevelopmental disorder. Our results broaden the phenotypic spectrum of this disorder and clarify the likely underlying disease mechanism for the condition. 


\section{MAIN TEXT}

\section{Introduction}

Copy number variants (CNVs) are an important cause for neurodevelopmental disorders (Cooper et al., 2013; Coe et al., 2013; Mefford et al.,2014). Disease causing CNVs result in diverse phenotypes and have significant medical and socioeconomic impact (Coppola et al.,2019; Burghel et al.,2020). Variability of CNVs can make their clinical correlation challenging. Individuals with overlapping CNVs can help in determining the minimum overlapping regions for specific disorders (Kasher et al.,2016). A significant proportion of copy number losses are driven by haploinsufficiency of dosage sensitive genes (Rice at al.,2017). Studying CNVs can, therefore, also provide insights into genetic basis of single gene (Yagi et al.,2003; Cuvertino et al.,2017) or complex disorders (Banka et al.,2015). Other mechanisms by which chromosome deletions can convey phenotypes include contiguous gene deletions, gene interruption, generation of fusion genes, unmasking of deleterious variants resulting in recessive phenotypes, epistasis, position effects such as disruption of the regulatory regions of the genome and disruption of topologically associating domains (TADs) (Stankiewicz et al.,2002; Lupski et al.,2005; Spielmann et al.,2018).

We recently contributed to the description of eight individuals with epilepsy, microcephaly, neurodevelopmental problems and overlapping $205 \mathrm{~kb}$ to $504 \mathrm{~kb} 16 \mathrm{p} 13.3$ microdeletions and proposed that it is a novel genetic condition (Table 1) (Mucha et al.,2019). The defined minimum critical region of $\sim 112 \mathrm{~kb}$ (GRCh37:Chr16:2,530,000-2,642,000) that included seven known genes - TBC1D24, ATP6VOC, AMDHD2, CEMP1, MIR3178, PDPK1 and $D Q 577714$. Since the original report, there has been no other peer-reviewed publication on this condition. The phenotypic spectrum, the minimum overlapping region and the underlying disease mechanism for this disorder remain to be clarified. Here we report an additional individual with an overlapping 16p13.3 deletion and a similar phenotype, which further establishes this microdeletion syndrome as a distinct entity. We also present results of in silico analysis that clarifies the possible underlying disease mechanism.

\section{Methods and Results}

\section{Case Report}

The proband is a 3.5-year-old male, born to non-consanguineous parents with no relevant family history. His mother's pregnancy was complicated by antenatal bleeding and placenta praevia. He was born via Caesarean section at 38 weeks gestation with a birth weight of $2.41 \mathrm{~kg}(-2 \mathrm{SD})$. The immediate postnatal period was uneventful apart from a brief period of hypothermia.

At the age of 10 months, the child presented with a tonic-clonic seizure during a febrile illness. Subsequently he had multiple febrile tonic-clonic seizures. 24-hour electroencephalograms did not show any epileptic activity. A brain magnetic resonance imaging scan at 1 year did not identify any abnormality. He has not been formally diagnosed with epilepsy and no anti-epileptic treatment has been required to be initiated so far. He 
first rolled over at the age of 10 months but then did not roll over again until several months later. He attained independent walking at 18 months of age. An Early Social cognitive Battery assessment performed at the age of 38 months showed his early social interaction and play skills to be impaired. An Autism Diagnostic Observation Schedule (ADOS Module 2) performed at 38 months of age showed him to be on moderate autism spectrum. Social affect score was 8 and restricted repetitive behaviours score of 1 with calibrated severity score of 5, meeting the criteria for autism spectrum disorder. Weschsler Preschool and Primary Scale of Intelligence - Fourth UK edition (WPPSI-IV) performed at 36 months of age gave a Full Scale Intelligence Quotient of 90 within the average range ( $25^{\text {th }}$ centile). His verbal comprehension index was 91 on the $27^{\text {th }}$ centile; (scaled scores: Receptive vocabulary = 10; Information =7) and Visual spatial index was 97 on the $42^{\text {nd }}$ centile (scaled scores: Block Design = 10; Object Assembly =9). Working memory and vocabulary index could not be computed due to lack of compliance but he scored within low average range for Picture memory (scaled score of 7) and Picture Naming (scaled score 7).

The child also has a history of frequent infections including recurrent upper respiratory tract infections, several episodes of glue ear and one episode of enteroviral meningitis. He also required tonsillectomy.

At age 2 years, the child's occipital frontal head circumference was $45 \mathrm{~cm}$ (-3SD), weight was $10.2 \mathrm{~kg}(-1.8 \mathrm{SD})$ and height was $84.6 \mathrm{~cm}(-0.25 \mathrm{SD})$. A neurological examination at this age was unremarkable. Facially the child is not dysmorphic.

Array comparative genomic hybridisation

Array comparative genomic hybridisation (a-CGH) analysis using OGT CytoSure Constitutional v3 Array (6x60K) revealed a 220kb loss of chromosome 16p13.3 ([GRCh37] 16p13.3(2,415,389_2,635,921)×1) (Figure 1A).The deletion encompassed eight known protein coding genes (CCNF, C16orf59, NTN3, TBC1D24, ATP6VOC, AMDHD2, CEMP1 and $P D P K 1)$ and two non-protein coding genes (MIR3178 and DQ577714).Targeted a-CGH performed on DNA samples of both parents revealed normal results indicating that the proband's deletion had occurred de novo. Comparison of the clinical features of our individual, with the phenotypes of previously published individuals (Table 1) showed remarkable overlap (Mucha et al.,2019). We, therefore, classed this deletion as pathogenic based on the joint consensus recommendation of the American College of Medical Genetics and Genomics (ACMG) and the Clinical Genome Resource (ClinGen) (Riggs et al., 2020). The variant details were uploaded on DECIPHER (\#363843).

\section{In silico analysis and literature review}

Combining our data with the previously published individuals revealed the minimum overlapping region for the condition to be 80Kb (GRCh37:chr16:2,555,682-2,635,921) encompassing five protein coding (TBC1D24, ATP6VOC, AMDHD2, CEMP1 and PDPK1) and two non-protein coding genes (MIR3178 and DQ577714) (Figure 1A). 
To investigate the possible disease mechanism, we first compiled the $\mathrm{pLI}$ and LOEUF scores of the genes in the deleted region (Table 2) (Karczewski et al.,2020). PDPK1 and ATP6VOC were found to have the highest $\mathrm{pLI}$ ( 0.98 and 0.74 respectively) and the lowest LOEUF $(0.29$ and 0.69 respectively) scores. Closer inspection of the gnomAD data revealed that the relatively low $\mathrm{pLI}$ and higher LOEUF scores of ATP6VOC are, at least in part, likely attributable to the relatively small size of this gene (only 3 exons encoding a protein of 155 amino acids). Furthermore, the only observed loss of function population variant is located in part of its exon 2 that is not included in two out of four known transcripts of the gene (Supplement Figure S1). Next, we obtained Gene Variation Intolerance Ranking (GeVIR) scores for the genes in this region (Table 2) (Abramovs et al.,2020). GeVIR is able to prioritize short genes, for which loss of function constraint cannot be estimated with confidence. Amongst the five protein coding genes ATP6VOC was found to be the highest ranked autosomal dominant disorder gene in GeVIR, followed by PDPK1. Next, we quantified the levels of gene expression in selected brain regions using GTEX portal (Figure 1B) (Supplement Table S1) (Gtex Consortium.2015). Expression of ATP6VOC was found to be highest across multiple brain tissues. Our analyses thus far indicated that the haploinsufficiency of PDPK1 or ATP6VOC or both possibly underlies 16p13.3 deletions that cause microcephaly, seizures and neurodevelopmental problems.

Next, we investigated the known functions, animal models and pathogenic point variants in these two genes in more detail. PDPK1 (also known as PDK1) encodes a protein kinase that is involved in intracellular signalling pathway facilitating cell migration (Bergfeld et al.,2012). PDPK1 murine knockout model is incompatible with life but mice with reduced residual PDK1 activity are smaller but fertile and without any obvious neurological phenotype (Alvarez-Pérez et al.,2006). No PDPK1 point variants were detected in ClinVar (Landrum et al.,2016). Three possible disease causing missense PDPK1 variants were listed in Human Gene Mutation Database (HGMD) (Stenson et al.,2003). However, the associated phenotypes were congenital heart defect (Russell et al.,2019), premature ovarian insufficiency (Oral et al.,2019) and modification of phenotype in Williams syndrome (Masson et al.,2019). None of these phenotypes overlap significantly with what has been observed in individuals with 16p13.3 deletions. ATP6VOC (ATPase, $\mathrm{H}+$ transporting, lysosomal $16 \mathrm{kDa}$, V0 subunit C) encodes for a component of vacuolar ATPase (V-ATPase), a subunit enzyme that acidifies the intracellular organelles of eukaryotes (Bayascas et al.,2008). This process maintains endocytic and exocytic pathways (Bayascas et al.,2008). The subunit is present in synaptic vesicles, endosomes, lysosomes, clathrin-coated vesicles, and the Golgi complex (Abbas et al.,2020). ATP6V0C has a neuron-specific expression at presynaptic vesicles in zebrafish embryos and facilities neurotransmitter storage (Wullschleger et al.,2011). An individual with Dravet syndrome and a de novo frameshift ATP6VOC variant has been previously reported (Carvill et al.,2014). De novo DB also lists a frameshift ATP6VOC identified in a proband in the Deciphering Developmental Disorders study (Deciphering Developmental Disorders Study., 2017 ;Tychele et al.,2017). ClinVar lists a single missense ATP6VOC variant of uncertain significance without any associated clinical data (Landrum et al.,2016).These analyses indicated that 
haploinsufficiency of ATP6VOC is more likely to explain the phenotype caused by $16 p 13.3$ deletions.

Next we considered the possibility of an epistatic model to explain the phenotype of 16p13.3 deletions (Veltman et al.,2010). We first looked for known interactions between the protein products of these genes. Protein-protein interaction network analysis was conducted using String (Szklarczyk et al.,2019) and the gene phenology was studied using Panther (Mi et al.,2019). These analyses did not reveal any known interactions or obvious functional overlaps (Supplement Tables S2 and S3). Finally we looked at the possibility of this deletion disrupting any TAD boundaries. Analysis of the deleted region by ClinTAD (https://www.clintad.com/, accessed April 2020) (Lupiáñez et al.,2016) showed that the breakpoints did not overlap with known TAD boundaries.

\section{Discussion}

We present a boy with microcephaly and autistic spectrum disorder (ASD) with a de novo chromosome 16p13.3 deletion, which spans between 2,415,389 and 2,635,921 [GRCh37]. The similarity of the phenotype of our individual with our eight recently described individuals and overlap of this deletion with the previously defined minimum critical region are strongly indicative that this deletion is causal (Mucha et al.,2019). Our observations further establish chromosome 16p13.3 deletion syndrome microcephaly, seizures and neurodevelopmental problems as a distinct genetic disorder. Of note, this condition should not be confused with other non-overlapping $16 \mathrm{p} 13.3$ deletions in this region resulting in alpha-thalassemia-intellectual disability syndrome (Babbs et al.,2020) or Rubinstein-Taybi syndrome (Breuning et al.,1993; Hennekam et al.,1993).

Epilepsy (including tonic clonic and myoclonic seizures) and microcephaly are the most frequent features in individuals with this syndrome (Mucha et al.,2019). Notably, although the individual reported here had history of febrile seizures, he has not been diagnosed as having epilepsy. The individual described in this study was diagnosed with ASD. Reported neuropsychiatric developmental disorders in the disorder include developmental delay (DD), Attention deficit hyperactivity disorder (ADHD), Intellectual disability (ID) and bipolar disorder (Mucha et al.,2019). Of note, the assessments in our patient suggest social communication impairments, but with average range cognitive ability. Our observations suggest that the phenotype of this condition is variable.

Our patient had history of repeated infections. None of the previous individuals have been reported to with this phenotype. At present it is not possible to be certain if this observation is linked to the 16p13.3 deletion or if it is coincidental. Of interest, PDPK1 has been reported to regulate macrophages metabolism, $T$ cells differentiation and $B$ cells haemostasis (Yang et al.,2016).

Previously the phenotype of this condition was attributed to haploinsufficiencies of TBC1D24, ATP6VOC and PDPK1. Our in silico analyses indicated that haploinsufficiency of either ATP6VOC or PDPK1 or both the genes may underlie the microcephaly, seizures and neurodevelopmental disorders in individuals with these $16 \mathrm{p} 13.3$ deletions. Of the two genes 
haploinsufficiency of ATP6VOC provides a more compelling explanation for the phenotype of this condition. It is because of its known function in acidification of synaptic vesicles (Bayascas et al.,2008), its high level of expression in brain tissues (Fig 1B), high GeVIR ranking (Table 2) and previous descriptions of individuals with frameshift variants and epilepsy or developmental disorders (Carvill et al.,2014; Deciphering Developmental Disorders Study, 2017)

Of note, the pLI score of ATP6VOC is only 0.74 , which is lower than expected for a gene, loss of function variants in which may cause a severe early-onset developmental disorder. However, our transcript-aware evaluation of population variants demonstrates that the deletions or loss of function variants that affect all the transcripts of this gene may be more deleterious than those variants which affect only some transcripts. TBC1D24 encodes a member of the Tre2-Bub2-Cdc16 (TBC) domain-containing RAB-specific GTPase-activating protein family (Falace et al.,2010). Bi-allelic TBC1D24 loss-of-function variants cause Deafness (OMIM 614617) (Rehman et al.,2014), DOORS syndrome (OMIM 220500) (Campeau et al.,2014), Rolandic epilepsy with paroxysmal exercise-induced dystonia and writer's cramp (OMIM 608105) (Luthy et al, 2019), Early Infantile Epileptic encephalopathy (OMIM 615338) (Duru et al.,2010) and infantile myoclonic epilepsy (OMIM 605021) (Falace et al.,2010). Heterozygous carriers of TBC1D24 loss-of-function variants do not show clinical features such as epilepsy, microcephaly or developmental delay. Of note, a heterozygous missense $\mathrm{p.(S178L)} \mathrm{TBC1D24}$ variant has been proposed to cause autosomal dominant deafness-65 (OMIM 616044) (Azaiez et al.,2014;Zhang et al.,2014). However, the proposed mechanism in this variant was gain of function or a dominant-negative. Heterozygous loss of $T B C 1 D 24$ is unlikely to be responsible for the phenotype seen with these deletions. Our analyses also indicate that epistatic or regulatory dysregulation are unlikely to explain the phenotypes of this condition. However, it is impossible to rule out the contribution to the phenotype from loss of other genes within the deletions without further studies.

In summary, we describe an additional individual with a rare chromosome $16 \mathrm{p} 13.3$ deletion that establishes the condition as a distinct entity and clarifies its phenotypic spectrum. Our analysis suggests that the haploinsufficiency of ATP6VOC is likely to underlie the pathology of this condition. Further data and experiments will be needed to prove these assertions conclusively. 


\section{REFERENCE}

Abbas, Y. M., Wu, D., Bueler, S. A., Robinson, C. V., \& Rubinstein, J. L. (2020). Structure of VATPase from the mammalian brain. Science, 367(6483), 1240-1246.

Abramovs, N., Brass, A., \& Tassabehji, M. (2020). GeVIR is a continuous gene-level metric that uses variant distribution patterns to prioritize disease candidate genes. Nature Genetics, 52(1), 35-39.

Ali, R. A., Rehman, A. U., Khan, S. N., Husnain, T., Riazuddin, S., Friedman, T. B., Ahmed, Z. M., \& Riazuddin, S. (2012). DFNB86, a novel autosomal recessive non-syndromic deafness locus on chromosome 16p13.3. Clinical Genetics, 81(5), 498-500.

Alvarez-Pérez, M. A., Narayanan, S., Zeichner-David, M., Rodríguez Carmona, B., \& Arzate, H. (2006). Molecular cloning, expression and immunolocalization of a novel human cementumderived protein (CP-23). Bone, 38(3), 409-419.

Azaiez, H., Booth, K. T., Bu, F., Huygen, P., Shibata, S. B., Shearer, A. E., Kolbe, D., Meyer, N., Black-Ziegelbein, E. A., \& Smith, R. J. H. (2014). TBC1D24 mutation causes autosomaldominant nonsyndromic hearing loss. Human Mutation, 35(7), 819-823.

Babbs, C., Brown, J., Horsley, S. W., Slater, J., Maifoshie, E., Kumar, S., Ooijevaar, P., Kriek, M., Dixon-Mclver, A., Harteveld, C. L., Traeger-Synodinos, J., Wilkie, A. O. M., Higgs, D. R., \& Buckle, V. J. (2020). ATR-16 syndrome: Mechanisms linking monosomy to phenotype. Journal of Medical Genetics.

Banka, S., Cain, S. A., Carim, S., Daly, S. B., Urquhart, J. E., Erdem, G., Harris, J., Bottomley, M., Donnai, D., Kerr, B., Kingston, H., Superti-Furga, A., Unger, S., Ennis, H., Worthington, J., Herrick, A. L., Merry, C. L. R., Yue, W. W., Kielty, C. M., \& Newman, W. G. (2015). Leri's pleonosteosis, a congenital rheumatic disease, results from microduplication at 8q22.1 encompassing GDF6 and SDC2 and provides insight into systemic sclerosis pathogenesis. Annals of the Rheumatic Diseases, 74(6), 1249-1256.

Bayascas, J. R., Wullschleger, S., Sakamoto, K., García-Martínez, J. M., Clacher, C., Komander, D., van Aalten, D. M. F., Boini, K. M., Lang, F., Lipina, C., Logie, L., Sutherland, C., Chudek, J. A., van Diepen, J. A., Voshol, P. J., Lucocq, J. M., \& Alessi, D. R. (2008). Mutation of the PDK1 $\mathrm{PH}$ domain inhibits protein kinase $\mathrm{B} / \mathrm{Akt}$, leading to small size and insulin resistance. Molecular and Cellular Biology, 28(10), 3258-3272.

Bergfeld, A. K., Pearce, O. M. T., Diaz, S. L., Pham, T., \& Varki, A. (2012). Metabolism of Vertebrate Amino Sugars with N-Glycolyl Groups. The Journal of Biological Chemistry, 287(34), 28865-28881.

Cuvertino, S., Stuart, H. M., Chandler, K. E., Roberts, N. A., Armstrong, R., Bernardini, L., Bhaskar, S., Callewaert, B., Clayton-Smith, J., Davalillo, C. H., Deshpande, C., Devriendt, K., 
Digilio, M. C., Dixit, A., Edwards, M., Friedman, J. M., Gonzalez-Meneses, A., Joss, S., Kerr, B., ... Banka, S. (2017). ACTB Loss-of-Function Mutations Result in a Pleiotropic Developmental Disorder. American Journal of Human Genetics, 101(6), 1021-1033.

DDD study, Deciphering Developmental Disorders Study. (2017). Prevalence and architecture of de novo mutations in developmental disorders. Nature, 542(7642), 433-438.

Breuning, M. H., Dauwerse, H. G., Fugazza, G., Saris, J. J., Spruit, L., Wijnen, H., Tommerup, N., van der Hagen, C. B., Imaizumi, K., Kuroki, Y., van den Boogaard, M.-J., de Pater, J. M., Mariman, E. C. M., Hamel, B. C. J., Himmelbauer, H., Frischauf, A.-M., Stallings, R. L., Beverstock, G. C., van Ommen, G.-J. B., \& Hennekam, R. C. M. (1993). Rubinstein-Taybi syndrome caused by submicroscopic deletions within 16p13.3. American Journal of Human Genetics, 52(2), 249-254.

Burghel, G. J., Khan, U., Lin, W.-Y., Whittaker, W., \& Banka, S. (2020). Presence of pathogenic copy number variants (CNVs) is correlated with socioeconomic status. Journal of Medical Genetics, 57(1), 70-72.

Campeau, P. M., Kasperaviciute, D., Lu, J. T., Burrage, L. C., Kim, C., Hori, M., Powell, B. R., Stewart, F., Félix, T. M., Ende, J. van den, Wisniewska, M., Kayserili, H., Rump, P., Nampoothiri, S., Aftimos, S., Mey, A., Nair, L. D. V., Begleiter, M. L., Bie, I. D., ... Sisodiya, S. M. (2014). The genetic basis of DOORS syndrome: An exome-sequencing study. The Lancet Neurology, 13(1), 44-58.

Carvill, G. L., Weckhuysen, S., McMahon, J. M., Hartmann, C., Møller, R. S., Hjalgrim, H., Cook, J., Geraghty, E., O’Roak, B. J., Petrou, S., Clarke, A., Gill, D., Sadleir, L. G., Muhle, H., von Spiczak, S., Nikanorova, M., Hodgson, B. L., Gazina, E. V., Suls, A., ... Mefford, H. C. (2014). GABRA1 and STXBP1: Novel genetic causes of Dravet syndrome. Neurology, 82(14), 1245-1253.

Coe, B. P., Witherspoon, K., Rosenfeld, J. A., van Bon, B. W. M., Vulto-van Silfhout, A. T., Bosco, P., Friend, K. L., Baker, C., Buono, S., Vissers, L. E. L. M., Schuurs-Hoeijmakers, J. H., Hoischen, A., Pfundt, R., Krumm, N., Carvill, G. L., Li, D., Amaral, D., Brown, N., Lockhart, P. J., ... Eichler, E. E. (2014). Refining analyses of copy number variation identifies specific genes associated with developmental delay. Nature Genetics, 46(10), 1063-1071.

Consortium, T. Gtex. (2015). The Genotype-Tissue Expression (GTEx) pilot analysis: Multitissue gene regulation in humans. Science, 348(6235), 648-660.

Cooper, G. M., Coe, B. P., Girirajan, S., Rosenfeld, J. A., Vu, T. H., Baker, C., Williams, C., Stalker, H., Hamid, R., Hannig, V., Abdel-Hamid, H., Bader, P., McCracken, E., Niyazov, D., Leppig, K., Thiese, H., Hummel, M., Alexander, N., Gorski, J., ... Eichler, E. E. (2011). A copy number variation morbidity map of developmental delay. Nature Genetics, 43(9), 838-846. 
Coppola, A., Cellini, E., Stamberger, H., Saarentaus, E., Cetica, V., Lal, D., Djémié, T., BartnikGlaska, M., Ceulemans, B., Helen Cross, J., Deconinck, T., Masi, S. D., Dorn, T., Guerrini, R., Hoffman-Zacharska, D., Kooy, F., Lagae, L., Lench, N., Lemke, J. R., ... EpiCNV Consortium. (2019). Diagnostic implications of genetic copy number variation in epilepsy plus. Epilepsia, 60(4), 689-706.

Stankiewicz, P., \& Lupski, J. R. (2002). Genome architecture, rearrangements and genomic disorders. Trends in Genetics, 18(2), 74-82.

Duru, N., Iseri, S. A. U., Selçuk, N., \& Tolun, A. (2010). Early-onset progressive myoclonic epilepsy with dystonia mapping to 16pter-p13.3. Journal of Neurogenetics, 24(4), 207-215.

Falace, A., Filipello, F., La Padula, V., Vanni, N., Madia, F., De Pietri Tonelli, D., de Falco, F. A., Striano, P., Dagna Bricarelli, F., Minetti, C., Benfenati, F., Fassio, A., \& Zara, F. (2010). TBC1D24, an ARF6-interacting protein, is mutated in familial infantile myoclonic epilepsy. American Journal of Human Genetics, 87(3), 365-370.

Hennekam, R. C., Tilanus, M., Hamel, B. C., Voshart-van Heeren, H., Mariman, E. C., van Beersum, S. E., van den Boogaard, M. J., \& Breuning, M. H. (1993). Deletion at chromosome 16 p13.3 as a cause of Rubinstein-Taybi syndrome: Clinical aspects. American Journal of Human Genetics, 52(2), 255-262.

Kasher, P. R., Schertz, K. E., Thomas, M., Jackson, A., Annunziata, S., Ballesta-Martinez, M. J., Campeau, P. M., Clayton, P. E., Eaton, J. L., Granata, T., Guillén-Navarro, E., Hernando, C., Laverriere, C. E., Liedén, A., Villa-Marcos, O., McEntagart, M., Nordgren, A., Pantaleoni, C., Pebrel-Richard, C., ... Banka, S. (2016). Small 6q16.1 Deletions Encompassing POU3F2 Cause Susceptibility to Obesity and Variable Developmental Delay with Intellectual Disability. American Journal of Human Genetics, 98(2), 363-372.

Karczewski, K. J., Francioli, L. C., Tiao, G., Cummings, B. B., Alföldi, J., Wang, Q., Collins, R. L., Laricchia, K. M., Ganna, A., Birnbaum, D. P., Gauthier, L. D., Brand, H., Solomonson, M., Watts, N. A., Rhodes, D., Singer-Berk, M., England, E. M., Seaby, E. G., Kosmicki, J. A., ... MacArthur, D. G. (2020). The mutational constraint spectrum quantified from variation in 141,456 humans. Nature, 581(7809), 434-443.

Landrum, M. J., Lee, J. M., Benson, M., Brown, G., Chao, C., Chitipiralla, S., Gu, B., Hart, J., Hoffman, D., Hoover, J., Jang, W., Katz, K., Ovetsky, M., Riley, G., Sethi, A., Tully, R., Villamarin-Salomon, R., Rubinstein, W., \& Maglott, D. R. (2016). ClinVar: Public archive of interpretations of clinically relevant variants. Nucleic Acids Research, 44(D1), D862-D868.

Lupiáñez, D. G., Spielmann, M., \& Mundlos, S. (2016). Breaking TADs: How Alterations of Chromatin Domains Result in Disease. Trends in Genetics: TIG, 32(4), 225-237.

Lupski, J. R., \& Stankiewicz, P. (2005). Genomic Disorders: Molecular Mechanisms for Rearrangements and Conveyed Phenotypes. PLOS Genetics, 1(6), e49. 
Lüthy, K., Mei, D., Fischer, B., De Fusco, M., Swerts, J., Paesmans, J., Parrini, E., Lubarr, N., Meijer, I. A., Mackenzie, K. M., Lee, W.-T., Cittaro, D., Aridon, P., Schoovaerts, N., Versées, W., Verstreken, P., Casari, G., \& Guerrini, R. (2019). TBC1D24-TLDc-related epilepsy exerciseinduced dystonia: Rescue by antioxidants in a disease model. Brain: A Journal of Neurology.

Masson, J., Demily, C., Chatron, N., Labalme, A., Rollat-Farnier, P.-A., Schluth-Bolard, C., Gilbert-Dussardier, B., Giuliano, F., Touraine, R., Tordjman, S., Verloes, A., Testa, G., Sanlaville, D., Edery, P., Lesca, G., \& Rossi, M. (2019). Molecular investigation, using chromosomal microarray and whole exome sequencing, of six patients affected by Williams Beuren syndrome and Autism Spectrum Disorder. Orphanet Journal of Rare Diseases, 14(1), 121.

Mefford, H. C. (2014). CNVs in Epilepsy. Current Genetic Medicine Reports, 2(3), 162-167.

Mi, H., Muruganujan, A., Ebert, D., Huang, X., \& Thomas, P. D. (2019). PANTHER version 14: More genomes, a new PANTHER GO-slim and improvements in enrichment analysis tools. Nucleic Acids Research, 47(D1), D419-D426.

Mucha, B. E., Banka, S., Ajeawung, N. F., Molidperee, S., Chen, G. G., Koenig, M. K., Adejumo, R. B., Till, M., Harbord, M., Perrier, R., Lemyre, E., Boucher, R.-M., Skotko, B. G., Waxler, J. L., Thomas, M. A., Hodge, J. C., Gecz, J., Nicholl, J., McGregor, L., ... Campeau, P. M. (2019). A new microdeletion syndrome involving TBC1D24, ATP6V0C, and PDPK1 causes epilepsy, microcephaly, and developmental delay. Genetics in Medicine: Official Journal of the American College of Medical Genetics, 21(5), 1058-1064.

Oral, E., Toksoy, G., Sofiyeva, N., Celik, H. G., Karaman, B., Basaran, S., Azami, A., \& Uyguner, Z. O. (2019). Clinical and Genetic Investigation of Premature Ovarian Insufficiency Cases from Turkey. Journal of Gynecology Obstetrics and Human Reproduction, 48(10), 817-823.

Rehman, A. U., Santos-Cortez, R. L. P., Morell, R. J., Drummond, M. C., Ito, T., Lee, K., Khan, A. A., Basra, M. A. R., Wasif, N., Ayub, M., Ali, R. A., Raza, S. I., Nickerson, D. A., Shendure, J., Bamshad, M., Riazuddin, S., Billington, N., Khan, S. N., Friedman, P. L., ... Friedman, T. B. (2014). Mutations in TBC1D24, a Gene Associated With Epilepsy, Also Cause Nonsyndromic Deafness DFNB86. American Journal of Human Genetics, 94(1), 144-152.

Rice, A. M., \& McLysaght, A. (2017). Dosage sensitivity is a major determinant of human copy number variant pathogenicity. Nature Communications, 8(1), 14366.

Riggs, E. R., Andersen, E. F., Cherry, A. M., Kantarci, S., Kearney, H., Patel, A., Raca, G., Ritter, D. I., South, S. T., Thorland, E. C., Pineda-Alvarez, D., Aradhya, S., \& Martin, C. L. (2020). Technical standards for the interpretation and reporting of constitutional copy-number variants: A joint consensus recommendation of the American College of Medical Genetics and Genomics (ACMG) and the Clinical Genome Resource (ClinGen). Genetics in Medicine: Official Journal of the American College of Medical Genetics, 22(2), 245-257. 
Russell, M. W., Moldenhauer, J. S., Rychik, J., Burnham, N. B., Zullo, E., Parry, S. I., Simmons, R. A., Elovitz, M. A., Nicolson, S. C., Linn, R. L., Johnson, M. P., Yu, S., Sampson, M. G., Hakonarson, H., \& Gaynor, J. W. (2019). Effect of parental origin of damaging variants in proangiogenic genes on fetal growth in patients with congenital heart defects: Data and analyses. Data in Brief, 25, 104311.

Turner, T. N., Yi, Q., Krumm, N., Huddleston, J., Hoekzema, K., F Stessman, H. A., Doebley, A.-L., Bernier, R. A., Nickerson, D. A., \& Eichler, E. E. (2017). denovo-db: A compendium of human de novo variants. Nucleic Acids Research, 45(D1), D804-D811.

Spielmann, M., Lupiáñez, D. G., \& Mundlos, S. (2018). Structural variation in the 3D genome. Nature Reviews Genetics, 19(7), 453-467.

Stenson, P. D., Ball, E. V., Mort, M., Phillips, A. D., Shiel, J. A., Thomas, N. S. T., Abeysinghe, S., Krawczak, M., \& Cooper, D. N. (2003). Human Gene Mutation Database (HGMD $\left.{ }^{\circledR}\right): 2003$ update. Human Mutation, 21(6), 577-581.

Szklarczyk, D., Gable, A. L., Lyon, D., Junge, A., Wyder, S., Huerta-Cepas, J., Simonovic, M., Doncheva, N. T., Morris, J. H., Bork, P., Jensen, L. J., \& Mering, C. von. (2019). STRING v11: Protein-protein association networks with increased coverage, supporting functional discovery in genome-wide experimental datasets. Nucleic Acids Research, 47(D1), D607D613.

Veltman, J. A., \& Brunner, H. G. (2010). Understanding variable expressivity in microdeletion syndromes. Nature Genetics, 42(3), 192-193.

Wullschleger, S., Wasserman, D. H., Gray, A., Sakamoto, K., \& Alessi, D. R. (2011). Role of TAPP1 and TAPP2 adaptor binding to PtdIns(3,4)P2 in regulating insulin sensitivity defined by knock-in analysis. The Biochemical Journal, 434(2), 265-274.

Yagi, H., Furutani, Y., Hamada, H., Sasaki, T., Asakawa, S., Minoshima, S., Ichida, F., Joo, K., Kimura, M., Imamura, S., Kamatani, N., Momma, K., Takao, A., Nakazawa, M., Shimizu, N., \& Matsuoka, R. (2003). Role of TBX1 in human del22q11.2 syndrome. Lancet (London, England), 362(9393), 1366-1373.

Yang, Y., Kong, W., Xia, Z., Xiao, L., \& Wang, S. (2016). Regulation mechanism of PDK1 on macrophage metabolism and function. Cell Biochemistry and Function, 34(8), 546-553.

Zhang, L., Hu, L., Chai, Y., Pang, X., Yang, T., \& Wu, H. (2014). A dominant mutation in the stereocilia-expressing gene TBC1D24 is a probable cause for nonsyndromic hearing impairment. Human Mutation, 35. 


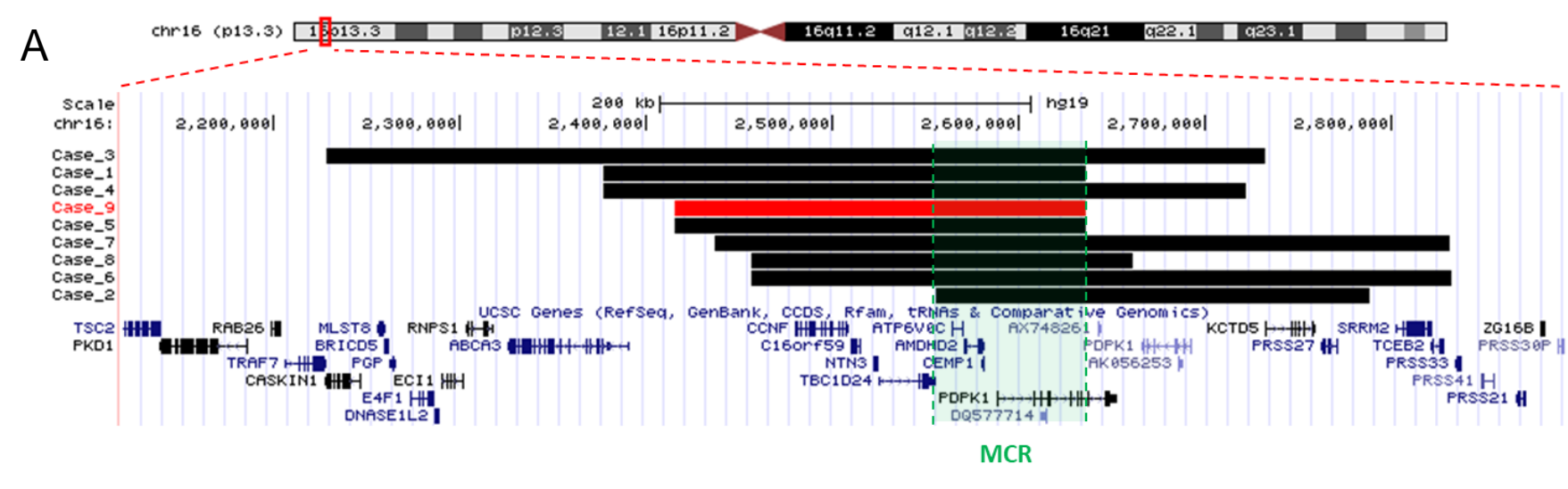

B
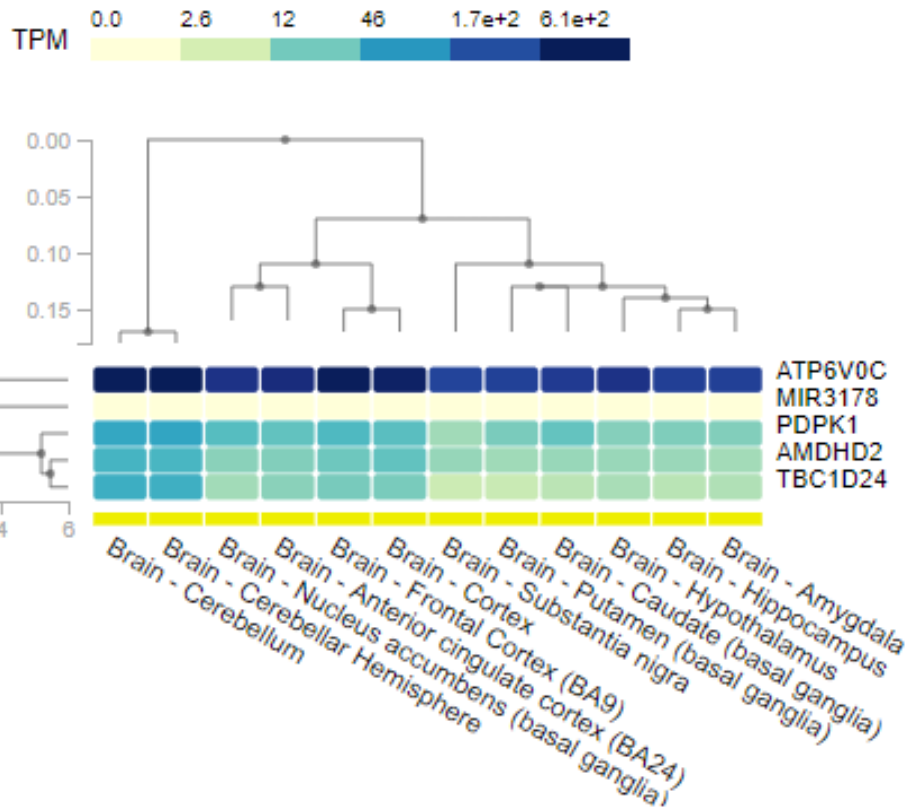